\title{
Pengaruh Kepatuhan Ibu Hamil dalam Mengkonsumsi Tablet Fe terhadap Kadar Hb Ibu Hamil Trimester III
}

\author{
Ratna Wulandari \\ Program Studi DIV Kebidanan Sekolah Tinggi Ilmu Kesehatan Indonesia Maju \\ Jln. Harapan Nomor 50, Lenteng Agung - Jakarta Selatan 12610 Telp: (021) 78894045 \\ Email :na_wulan@ymail.com
}

\begin{abstract}
Abstrak
Anemia merupakan kondisi yang normal pada ibu hamil dalam batas kadar Haemoglobin (Hb) dalam darah $11 \mathrm{gr} \%$, jika kurang dari itu maka diperlukan tindakan khusus, seperti pemberian terapi tablet Fe (zat besi) yang saat ini tengah digalakkan oleh pemerintah dalam program 90 tablet $\mathrm{Fe}$ pada ibu hamil untuk mencegah terjadinya anemia yang berlanjut pada kehamilan. Tujuan penelitian ini adalah untuk mengetahui pengaruh kepatuhan ibu hamil dalam mengkonsumsi tablet Fe terhadap kadar $\mathrm{Hb}$ pada ibu hamil trimester III di Puskesmas Kecamatan Pasar Minggu Jakarta Selatan Tahun 2015.Desain penelitian yang digunakan adalah kuantitatif dengan pendekatan case control. Populasi dalam penelitian ini adalah ibu hamil trimester III yang melakukan pemeriksaan kehamilan di Puskesmas Kecamatan Pasar Minggu, sebanyak 82 responden. Cara pengambilan sampel menggunakan metode purposive sampling berjumlah 47 responeden. Hasil analisis univariat menunjukkan, dari 47 responden terdapat $61,7 \%$ ibu yang patuh dalam mengkonsumsi tablet $\mathrm{Fe}$ dan terdapat $31,9 \%$ yang mengalami anemia, sedangkan pada analisis bivariat menunjukkan dengan menggunakan uji korelasi pearson kepatuhan responden dalam mengkonsumsi tablet Fe dengan kadar Hb menghasilkan $p$ (value $)=0,756$ dan dengan uji regresi didapatkan hasil R-square 0,572. Kesimpulan dari penelitian ini adalah perilaku kepatuhan ibu hamil dalam mengkonsumsi tablet Fe berhubungan sangat signifikan dengan kadar $\mathrm{Hb}$ dengan proporsi pengaruhnya adalah $57,2 \%$.
\end{abstract}

Kata Kunci : : Fe, Haemoglobin, Kepatuhan

\begin{abstract}
Anemia is a condition that is normal in pregnant women if the levels of Haemoglobin (Hb) in the blood is $11 \mathrm{gr} \%$, if less than it they need special measures, such as therapy tablets Fe (iron) which have been promoted by the government in program of 90 tablet Fe for pregnant women to prevent continuing anemia in pregnancy. The purpose of this study is to know the influence of compliance pregnant women in consuming Fe tablet to determine Hb level in the 3rd trimester of pregnancy in Puskesmas Kecamatan Pasar Minggu, South Jakarta year 2015. Desain of this research is quantitative with case control approach. The population in this study is pregnant women in the 3rd trimester who are checking health in Puskesmas Pasar Minggu, there are 82 respondents. The sampling is using purposive sampling method amounted to 47 respondents. The results of univariate analysis showed that from 47 respondents, 61,7\% of women are obedient in consuming Fe tablets and $31,9 \%$ are anemic, and in the bivariate analysis using pearson correlation test showed that the influence of pregnant woman in consuming tablet fe to determine $\mathrm{Hb}$ level has result of $p$ (value) $=0,756$ and the regression test showed $R$-square is 0,572 . The conclusion on this study is the compliance pregnant women in consuming Fe tablet has significantly influence to determine hemoglobin levels with the proportion of influence is $57.2 \%$.
\end{abstract}

Keywords: Fe, Haemoglobin, Compliance 


\section{Pendahuluan}

Menurut Proverawati anemia adalah suatu keadaan dimana tubuh memiliki jumlah sel darah merah (eritrosit) yang terlalu sedikit, yang mana sel darah merah tersebut mengandung Haemoglobin $(\mathrm{Hb})$ yang berfungsi untuk membawa oksigen ke seluruh jaringan tubuh. ${ }^{1}$ Menurut Dinas Kesehatan Provinsi DKI Jakarta anemia pada ibu hamil merupakan penyebab perdarahan pada saat ibu bersalin yang merupakan penyebab Angka Kematian Ibu (AKI) tertinggi kedua yakni $31 \% .^{2}$

Pemerintah Indonesia melalui Departemen Kesehatan Republik Indonesia telah memberikan program bagi para ibu hamil di Indonesia untuk mengkonsumsi minimal 90 tablet besi selama kehamilan. ${ }^{3}$ Hasil penelitian mahasiswa FKM UI bekerjasama dengan Micronutrient Initative Indonesia (MII) pada tahun 2012 diketahui bahwa rata-rata hanya 15 tablet $\mathrm{Fe}$ yang dikonsumsi oleh wanita hamil. $^{4}$

Menurut World Health Organization WHO tahun 2011, secara global prevalensi anemia pada ibu hamil di seluruh dunia adalah sebesar $38 \%$ (32,4 juta). Prevalensi anemia pada ibu hamil diperkirakan di Asia tertinggi kedua setelah Afrika, yakni mencapai 48,2 \%. Berdasarkan hasil Riset Kesehatan Dasar (Riskesdas) tahun 2013, prevalensi anemia pada ibu hamil di Indonesia sebesar $37,1 \%$ dan disebutkan bahwa $89,1 \%$ ibu hamil telah diberikan tablet tambah darah, namun hanya $33,3 \%$ saja yang rutin mengkonsumsi minimal 90 tablet Fe pada kehamilan. ${ }^{6}$

Di provinsi DKI Jakarta, kejadian anemia $41,8 \%$, dengan ibu hamil yang tercatat telah mendapatkan 90 tablet Fe selama kehamilan $94,8 \%$, dan yang tertinggi di wilayah Jakarta Selatan yakni $96,00 \%{ }^{7}$ Menurut Profil Kesehatan Jakarta Selatan, kasus anemia pada ibu hamil mencapai 26\%. Dari 11 Puskesmas Kecamatan yang berada di wilayah Jakarta Selatan, Puskesmas Kecamatan Pasar Minggu termasuk kedalam 3 puskesmas dengan angka distribusi $\mathrm{Fe}$ tertinggi, yakni distribusi $\mathrm{Fe}$ I sebanyak $98,8 \%$, dan Fe III sebesar $94,2 \%^{8}$, namun prevalensi kejadian anemia masih cukup besar yakni 30,6\%. ${ }^{8}$

Puskesmas merupakan salah satu badan pelayanan kesehatan yang diharapkan mampu menjangkau kesehatan seluruh lapisan masyarakat dan sebagai sumber informasi utama dalam penilaian kesehatan wilayah yang dinaunginya. Salah satunya adalah penilaian tentang cakupan distribusi $\mathrm{Fe}$ dan proporsi ibu hamil yang mengalami anemia di wilayah kerja puskesmas. Namun bila dilihat data dari Puskesmas Pasar Minggu Jakarta Selatan, sebesar 94,2\% ibu hamil telah mendapatkan $\mathrm{Fe}$ III atau 90 tablet Fe selama kehamilan, namun masih terdapat $30,6 \%$ kejadian anemia pada ibu hamil.

Melihat tingginya cakupan ditribusi tablet $\mathrm{Fe}$ sebanding dengan tingginya kejadian anemia, maka peneliti ingin mengetahui pengaruh kepatuhan ibu hamil dalam mengkonsumsi tablet Fe terhadap kadar $\mathrm{Hb}$ di wilayah kerja Puskesmas Kec. Pasar Minggu Jakarta Selatan Tahun 2015.

Berdasarkan hal tersebut maka peneliti tertarik untuk mengetahui bagaimana pengaruh tingkatan kepatuhan ibu hamil dalam mengkonsumsi tablet $\mathrm{Fe}$ terhadap kadar Haemoglobin ( $\mathrm{Hb})$ ibu hamil trimester III di Puskesmas Kec. Pasar Minggu Jakarta Selatan Tahun 2015. Melalui penelitian tersebut diharapkan dapat memberikan kontribusi positif dalam rangka evaluasi program minimal 90 tablet Fe pada ibu hamil.

Tujuan dari penelitian ini adalah diperolehnya data proporsi kepatuhan ibu hamil dalam mengkonsumsi tablet $\mathrm{Fe}$ yang mempengaruhi kadar $\mathrm{Hb}$ pada ibu hamil trimester III di wilayah kerja Puskesmas Kec. Pasar Minggu Jakarta Selatan. Kepatuhan dalam kesehatan artinya perilaku patuh pasien terhadap anjuran petugas kesehatan, dalam hal ini kepatuhan ibu hamil dalam mengkonsumsi tablet Fe.

Pada identifikasi awal kepatuhan ibu hamil dalam mengkonsumsi tablet $\mathrm{Fe}$ adalah mengetahui tingkat pengetahuan ibu hamil tentang tablet $\mathrm{Fe}$, jenjang pendidikan dan frekuensi ANC pada ibu hamil. Pengetahuan ibu hamil tentang tablet $\mathrm{Fe}$ mempengaruhi motivasi ibu dalam mengikuti anjuran petugas kesehatan, jika ibu memahami manfaat tablet

Fe maka ibu akan termotivasi untuk mengikuti anjuran petugas kesehatan dalam mengkonsumsi tablet Fe. Jenjang pendidikan berpengaruh secara tidak langsung terhadap pola pikir ibu hamil dalam memberikan 
keputusan untuk menuruti atau tidak anjuran dalam mengkonsumsi tablet $\mathrm{Fe}$.

Frekuensi periksa kehamilan juga berpengaruh, semakin sering atau rutin ibu hamil memeriksakan kesehatannya maka semakin baik, hal ini dikarenakan dalam setiap pemeriksaan kehamilan ibu hamil akan dipantau konsumsi zat besi serta mendapatkan tambahan konseling mengenai pentingnya tablet Fe dalam kehamilan.

Haemoglobin merupakan senyawa gabungan dari zat besi dan protein yang berada di dalam sel darah merah, yang berfungis mengikat oksigen dan mengedarkannya ke seluruh tubuh melaui aliran darah. Ibu hamil mengalami proses hemodilusi yakni proses pengenceran darah sebagai adapatasi ibu terhadap pertumbuhan janin, plasenta, dan payudara. Hal ini penyebabkan sel-sel darah merah ikut berkurang, dengan kata lain kadar haemoglobin ikut berkurang. Badan kesehatan dunia atau World Health Organization (WHO) memperkirakan bahwa 35-75\% ibu hamil di negara berkembang dan $18 \%$ ibu hamil di negara maju mengalami anemia.

Anemia defisiensi besi pada wanita hamil merupakan problema kesehatan yang dialami oleh wanita diseluruh dunia terutama di Negara berkembang (Indonesia). WHO (World Health Organization) melaporkan bahwa prevalensi wanita hamil yang mengalami defisiensi sekitar $35-75 \%$ serta semakin meningkat seiring dengan bertambah usia kehamilan.

Kadar haemoglobin yang kurang atau menurun pada ibu hamil merupakan hal fisiologis, namun bila tidak segera diatasi akan menjadi patologis yang membahayakan kesehatan ibu dan janin. Kadar haemoglobin normal pada ibu hamil adalah diatas $11 \mathrm{gr} / \mathrm{dL}$, jika kurang dari itu maka disebut anemia. Anemia yang paling sering pada ibu hamil adalah anemia defisienesi besi.

Berdasarkan pendapat pada ahli maka dapat disimpulkan bahwa kepatuhan ibu hamil dalam mengkumsi tablet $\mathrm{Fe}$ atau tablet zat besi atau tablet tambah darah merupakan serangkaian perilaku ibu hamil dalam mengkonsumsi suplemen $\mathrm{Fe}$, yang meliputi ketepatan dosis, ketepatan cara, dan ketepatan frekuensi.
Ketepatan dosis yang dimaksud adalah tablet Fe yang dikonsumsi berisi $60 \mathrm{mg}$ sulfas ferrous (zat besi) per tablet dikonsumsi satu tablet per hari selama hamil. Ketepatan cara yakni minum tablet $\mathrm{Fe}$ dengan air putih, tidak dengan air teh atau kopi atau susu, karena dapat menghambat penyerapan zat besi, serta diminum setelah makan malam menjelang tidur untuk menghindari mual yang berlebihan. Sedangkan ketepatan frekuensi yang dimaksud adalah dalam satu hari mengkonsumsi satu tablet Fe, setiap hari selama kehamilan, jumlah yang dikonsumsi minimal 90 tablet selama kehamilan, serta tidak menghentikan konsumsi tablet Fe sebelum melakukan konsultasi pada petugas kesehatan.

Jika konsumsi tablet Fe dilakukan sesuai anjuran akan mencegah terjadinya anemia kehamilan, yakni kadar haemoglobin dibawah $11 \mathrm{gr} / \mathrm{dL}$ pada ibu hamil. Haemoglobin $(\mathrm{Hb})$ merupakan senyawa gabungan dari protein dan zat besi. Adanya protein tanpa zat besi tidak dapat membentuk senyawa hemoglobin, sehingga diperlukan asupan zat besi lebih untuk mengganti jumlah zat besi yang berkurang akibat proses pengenceran darah dalam proses pertumbuhan plasenta, janin dan payudara ibu.

Pemeriksaan $\mathrm{Hb}$ dianjurkan minimal 2 kali pada trimester pertama dan ketiga kehamilan. Klasifikasi kadar $\mathrm{Hb}$ adalah sebagai berikut :
$\mathrm{Hb} \geq 11 \mathrm{gr} \%$
: Tidak anemia
Hb 9-10 gr\%
: Anemia ringan
$\mathrm{Hb} 7-8 \mathrm{gr} \%$
: Anemia sedang
$\mathrm{Hb}<7 \mathrm{gr} \%$
: Anemia berat

Untuk itu kepatuhan ibu hamil dalam mengkonsumsi tablet $\mathrm{Fe}$ diperlukan sebagai usaha dalam menjaga kadar $\mathrm{Hb}$ tetap normal, sehingga mengurangi kemungkinan terjadinya komplikasi pada ibu dan janin. Salah satunya dengan mengetahui bagaimana kepatuhan ibu hamil dalam menjalankan anjuran dari pemerintah yakni mengkonsumsi minimal 90 tablet $\mathrm{Fe}$ selama kehamilan untuk mencegah anemia yang berlanjut pada ibu hamil.

\section{Metode}

Menurut Wawan (2010) desain penelitian merupakan strategi untuk mendapatkan data yang dibutuhkan untuk keperluan pengujian 
hipotesis atau untuk menjawab pertanyaan penelitian dan sebagai alat untuk mengontrol variabel yang berpengaruh dalam penelitian. ${ }^{9}$

Desain penelitian yang digunakan dalam penelitian ini adalah kuantitatif, dengan rancangan penelitian kasus control (case control). Menurut Notoatmodjo (2012) rancangan penelitian kasus kontrol adalah bagaimana faktor resiko dipelajari dengan menggunakan pandekatan retrospective, dengan kata lain, efek (penyakit atau status kesehatan) diidentifikasi pada saat ini, kemudian faktor resiko diidentifikasi adanya atau terjadinya pada waktu yang lalu. ${ }^{10}$

Data yang dikumpulkan adalah data primer dan sekunder untuk mengetahui pengaruh kepatuhan ibu hamil dalam mengkonsumsi tablet Fe terhadap kadar $\mathrm{Hb}$ ibu trimester I, II, III pada bulan Juni 2015.

Penelitian ini dilakukan di Puskesmas Pasar Minggu Jakarta Selatan. Pemilihan lokasi ini dilakukan secara sengaja dengan pertimbangan Puskesmas Pasar Minggu merupakan Puskesmas dengan angka ditribusi tablet Fe termasuk 3 tertinggi di Jakarta Selatan, yang Jakarta Selatan sendiri merupakan daerah dengan angka ditribusi tablet Fe tertinggi di DKI Jakarta, Ibu Kota Indonesia.

Populasi adalah keseluruhan objek penelitian atau objek yang diteliti. Populasi dalam penelitian ini adalah semua ibu hamil yang melakukan kunjungan Antenatal Care (ANC) di Puskesmas Pasar Minggu pada bulan Juni 2015. Populasi pada penelitian ini berjumlah 82 ibu hamil trimester III.

Sampel adalah bagian dari jumlah dan karakteristik yang dimiliki populasi. ${ }^{11}$ Pada penelitian ini teknik sampling yang digunakan adalah purposive sampling yaitu teknik penentuan sampel dengan cara memilih sampel diantara populasi sesuai dengan yang dikehendaki penelitian (tujuan/ masalah dalam penelitian), sehingga sampel tersebut dapat mewakili karakteristik popuslasi yang telah dikenal sebelumnya. ${ }^{12}$

Teknik yang digunakan dalam pengumpulan data adalah dengan memberikan pertanyaan melalui kuesioner dengan metode purposive sampling, yakni memilih responden yang sesuai dengan karakteristik yang diperlukan dalam penelitian. Berdasarkan jumlah perhitungan sampel menurut Sugiyono (2007) dari 82 populasi jumlah sampel minimal yang diperlukan adalah 45 responden.

Kriteria inklusi adalah karakteristik umum dari subyek penelitian dari suatu populasi target yang terjangkau dan akan diteliti. ${ }^{13}$ Kriteria inklusi dalam penelitian ini adalah ibu hamil yang periksa kehamilan di Puskesmas Pasar Minggu Jakarta Selatan, sedang dalam masa trimester III kehamilan, sekurangkurangnya telah melakukan pemeriksaan $\mathrm{Hb} 2$ kali, yakni pada trimester I dan trimester III kehamilan dan hasilnya tercatat, dan pada pemeriksaan $\mathrm{Hb}$ pertama kali hasilnya menunjukkan ibu tidak anemia atau $\mathrm{Hb}$ minimal 11gr\%. Krieria ekskulsi adalah menghilangkan atau mengeluarkan subyek yang tidak memenuhi kriteria inklusi dari penelitian. ${ }^{14}$

Pada penelitian ini kriteria ekskulsi adalah ibu hamil yang melakukan pemeriksaan selain di Puskesmas Pasar Minggu Jakarta Selatan, usia kehamilan dibawah 28 minggu, dan ibu hamil yang belum melakukan pemeriksaan $\mathrm{Hb}$ atau sudah melakukan pemeriksaan $\mathrm{Hb}$ namun pada pemeriksaan $\mathrm{Hb}$ pertama hasilnya dibawah $11 \mathrm{gr} \%$.

Proses pemberian kode untuk memudahkan pengumpulan data dan pengelompokan data. Coding merupakan proses untuk mengklarifikasi data dan memberikan kode untuk masing-masing variabel sesuai dengan tujuan pengumpulan data. Kode angka untuk setiap jawaban adalah $1-5$.

Coding pada kuesioner dengan skala Likert, dengan pertanyaan positif akan diberi penilaian sebagai berikut:

SSS (Sangat Setuju Sekali) : nilai 5

SS (Sangat Setuju) : nilai 4

$\mathrm{R}$ (Ragu) : nilai 3

TS (Tidak Setuju) : nilai 2

STS (Sangat Tidak Setuju) : nilai 1

Tidak menjawab : nilai 0

Metode pengukuran untuk variabel independen menggunakan kuesioner dengan skala Likert, dengan rentang skor 1-5. Setiap pertanyaan positif diberi nilai paling besar, dan pertanyaan negatif diberi nilai paling kecil. ${ }^{15}$

Sedangkan variabel dependen diperoleh tidak melalui pengukuran sendiri namun pengukuran menggunakan alat pemeriksaan 
darah, yang hasilnya dicatat dalam bentuk data sekunder.

Cara pengumpulan data primer yang digunakan dalam penelitian ini melalui alat bantu berupa pertanyaan melalui penyebaran kuesioner, yang dilakukan oleh peneliti kepada responden yang sesuai dengan kriteria yang ditetapkan dengan kisi-kisi dalam pembuatan butir pertanyaan dapat dijelaskan melalui tabel pokok bahasan kuesioner sebagai berikut :

Tabel 1. Pokok Bahasan Kuesioner

\begin{tabular}{llcc}
\hline No. & \multicolumn{1}{c}{ Bahasan } & $\begin{array}{c}\text { Sebaran } \\
\text { Butiran }\end{array}$ & Jumlah \\
\hline 1 & Tablet Fe & $1-9$ & 9 \\
2 & Tepat dosis & $10-16$ & 7 \\
3 & Tepat cara & $17-21$ & 5 \\
4 & Tepat Frekuensi & $22-30$ & 9 \\
5 & Pemeriksaan Hb & $31-40$ & 10 \\
\hline & Jumlah & $1-40$ & 40 \\
\hline
\end{tabular}

Masing-masing bahasan pertanyaan terdiri dari pertanyaann positif dan pertanyaan negatif yang disusun secara acak.

Pada uji coba di lapangan merupakan bagian dari proses validasi empirik. Melalui uji coba tersebut, instrument diberikan kepada sejumlah responden sebagai sampel uji coba yang mempunyai karakteristik sama atau ekuivalen dengan karakteristik populasi penelitian.

Uji validitas dan reliabilititas dilakukan untuk mengetahui apakah instrument yang dilakukan betul mengukur apa yang perlu diukur dan sejauh mana instrument dapat dipercaya atau diandalkan. Uji validitas dan reliabilitas dengan menggunakan SPSS for Windows Versi 18.

Uji validitas dilakukan di Puskesmas Kelurahan Pasar Minggu 02 di Jalan Ragunan Raya dengan jumlah sampel uji coba sebanyak 20 responden. Jawaban atau respon dari sampel uji coba merupakan data empiris yang akan dianalisis untuk menguji validitas empiris atau validitas kriteria yang dikembangkan.

Pada uji validitas, butir pertanyaan dinyatakan valid jika nilai $r$ hitung lebih besar dari $r$ tabel. Nilai $r$ hitung dapat dilihat pada kolom Corrected Item Total Correlation pada output hasil uji validitas menggunakan SPSS 18. Sedangkan nilai $r$ tabel dilihat pada nilai $r$ tabel Fisher and Yates, sesuai dengan nilai df atau derajat kebebasan dengan rumus $\mathrm{df}=\mathrm{n}-$
2, dengan $\mathrm{n}$ adalah jumlah sampel. Jumlah sampel yang digunakan pada uji validitas dan reliabilitas instrument adalah 20, sehingga nilai df $=20-2=18$. Berdasarkan modul analisis data Departemen Kesehatan Republik Indonesia, nilai df 18 pada tingkat kemaknaan $5 \%$, didapat nilai $\mathrm{r}$ tabel $=0,444$. Sehingga pertanyaan akan valid jika nilai pada kolom Corrected Item Total Correlation nilainya lebih dari $0,444{ }^{16}$

Sampel uji coba yang didapatkan adalah 20 responden, dengan 40 butir pertanyaan pada kuesioner. Pengujian validitas butir pertanyaan kuesioner pada variabel kepatuhan dalam mengkonsumsi tablet $\mathrm{Fe}$ menggunakan SPSS 18, dan pada output menghasilkan angka yang menunjukkan bahwa seluruh pertanyaan valid.

Reliabilitas menunjukkan suatu instrument cukup dapat dipercaya untuk digunakan sebagai alat pengumpulan data. Analisis reliabilitas menggunakan cara yang sama dengan uji validitas, namun pada uji reabilitas kolom yang diperhatikan adalah pada kolom output SPSS for Windows 18 pada kolom Cronbach's Alpha atau disebut nilai r Alpha. Variabel dinyatakan reliable jika nilai $r$ Alpha $>\mathrm{r}$ tabel, yakni 0,444. Sehingga variabel dinyatakan reliable jika nilai r Alpha $>0,444 .{ }^{17}$

Hasil output uji reliabilitas menghasilkan angka 0,954, yang menunjukkan bahawa pertanyaan-pertanyaan kuesioner reliabel. Data diolah meggunakan software SPSS for Windows Versi 18. Yang hasilnya meliputi analisis univariat dan analisis bivariat. Analisis univariat adalah analisis yang dilakukan terhadap setiap variabel dari hasil pemelitian yang menghasilkan dan presentasi dari tiap variabel. ${ }^{18}$

Tujuan dari analisis ini bertujuan untuk menjelaskan dan mendeskripsikan karakteristik masing-masing variable yang diteliti. Analisis deksriptif yang akan disajikan meliputi karakteristik responden, analisis deskriptif data kategorik pada variabel independen dan analisis data numerik pada variabel variabel dependen. Pada analisis deskriptif yang disajikan adalah angka rata-rata, nilai tengah, standar deviasi (variasi), jarak inter kuartil, minimal dan maksimal. Pada analisis univariat variable independen, hasil jawaban responden akan diakumulasikan, dan dikelompokkan 
dalam skala interval melalui metode Method of Succesive Interval (MSI).

Proses pentransformasian data ordinal menjadi data interval dalam penelitian ini menggunakan bantuan program komputer yaitu Microsoft Office Excel, dengan hasil sebagai berikut :

Jika total nilai $\geq 150 \quad$ : sangat patuh

Jika total nilai $\geq 140 \quad$ : patuh

Jika total nilai $\geq 130 \quad$ : kurang patuh

Jika total nilai $\geq 120 \quad$ : tidak patuh

Jika total nilai $\leq 110 \quad$ : sangat tidak patuh

Sedangkan pada anlisis univariat variable dependen, kadar $\mathrm{Hb}$ yang telah dicatat akan dikelompokkan dalam interval sesuai dengan teori kategori anemia, sebagai berikut :

Jika $\geq 12 \mathrm{gr} \% \quad:$ kadar $\mathrm{Hb}$ tinggi

Jika $\geq 11$ gr\% $\quad$ : kadar Hb cukup

Jika $\geq 9$ gr\% $\quad$ : kadar Hb kurang

Jika $\geq 7 \mathrm{gr} \% \quad:$ kadar $\mathrm{Hb}$ rendah

Jika $\leq 7 \mathrm{gr} \% \quad$ : kadar Hb sangat rendah

Setelah diketahui karakteristik masingmasing variable dapat diteruskan analisis lebih lanjut atau analisis antara dua variable yakni analisis bivariat. Analisa ini dilakukan untuk menguji hipotesa hubungan dua variabel yang diduga mempunyai hubungan. Analisa ini membuktikan ada tidaknya hubungan antar variabel bebas dengan variabel terikat.

Dalam penelitian ini menggunakan uji korelasi karena data yang digunakan dalam bentuk data numerik. Analisis ini bertujuan untuk menguji perbedaan proporsi dua atau lebih kelompok sampel, dalam hal ini uji yang cocok digunakan adalah uji korelasi. ${ }^{19}$

Sebelum dilakukan uji Korelasi maka harus dilakukan uji Asumsi, yakni uji normalitas, linearitas data. Pada uji normalitas, jika sampel yang didapat $>50$ maka menggunakan uji normalitas Kolomogorov Smirnov, namun jika sampel $\leq 50$ maka lebih baik yang digunakan uji normalitas Shapiro Wilk. Pada uji normalitas, data berdistribusi normal jika didapatkan nilai $\mathrm{p}$ value $>0,05$. Sama halnya dengan uji normalitas, pada uji linearitas, jika nilai pada $\mathrm{p}$ value $>0,05$, maka data dianggap linier.

Jika data telah berdisribusi normal dan linier maka data bisa diolah dengan uji korelasi. Untuk menguji kemaknaan hubungan antara variabel dependen dan independen digunakan derajat kepercayaan $95 \%(\alpha=0,05)$. Apabila $\mathrm{p}$ value $\leq 0,05$ berarti ada hubungan yang bermakna/ signifikan antara variabel independen dengan variabel dependen.

Untuk mengetahui lebih tepat besar derajat hubungan dua variabel digunakan Koefisien Korelasi Pearson Product Moment, dimana koefisien korelasi disimbolkan dengan huruf $r$ (huruf kecil). Nilai koefisien korelasi (r) berkisar $0 \mathrm{~s} / \mathrm{d} 1$ atau bila dengan arahnya nilainya antara $-1 \mathrm{~s} / \mathrm{d}$ 1. Hubungan dua variabel dapat berpola positif maupun negatif. Hubungan positif bila kenaikan variabel yang satu diiikuti oleh kenaikan variabel yang lain. Sedangkan hubungan negative bila kenaikan satu variabel diikuti penurunan variabel yang lain.

Untuk mengetahui lebih tepat besar derajat hubungan dua variabel digunakan Koefisien Korelasi Pearson Product Moment, dimana koefisien korelasi disimbolkan dengan huruf $r$ (huruf kecil). Nilai koefisien korelasi (r) berkisar $0 \mathrm{~s} / \mathrm{d} 1$ atau bila dengan arahnya nilainya antara $-1 \mathrm{~s} / \mathrm{d} 1 .^{20}$

$r=0 \rightarrow$ tidak ada hubungan linier

$\mathrm{r}=-1 \rightarrow$ hubungan linear negative sempurna

$\mathrm{r}=+1 \rightarrow$ hubungan linear positif sempurna

Hubungan dua variabel dapat berpola positif maupun negatif. Hubungan positif bila kenaikan variabel yang satu diiikuti oleh kenaikan variabel yang lain. Sedangkan hubungan negative bila kenaikan satu variabel diikuti penurunan variabel yang lain. Menurut Colton, kekuatan dapat dibagi menjadi 4 area yaitu:

$\mathrm{r}=0,00-0,25 \rightarrow$ Tidak ada hubungan/ hubungan lemah

$\mathrm{r}=0,26-0,50 \rightarrow$ Hubungan sedang

$\mathrm{r}=0,51-0,75 \rightarrow$ Hubungan kuat

$\mathrm{r}=0,76-1,00 \rightarrow$ Hubungan sangat kuat/

sempurna. ${ }^{21}$

Jika telah diuji korelasi memiliki korelasi minimal sedang, maka akan dilakukan uji regresi, untuk mengetahui seberapa besar pengaruh variable independen terhadap variable dependen. Pada uji regresi jika hasil $\mathrm{p}$ (value) pada uji anova bernilai <0,05 maka terdapat perbedaan rata-rata pada populasi sehingga dapat dilanjutkan untuk mencari persamaan regresi.

Penyajian data dengan narasi (kalimat) atau memberikan keterangan secara tulisan. Seperti keterangan dalam pengumpulan data dalam bentuk tertulis mulai dari pengambilan 
sampel, pelaksanaan pengumpulan data sampai hasil analisis yang berupa informasi dari pengumpulan data tersebut, dan interpretasi atau penjabaran hasil analisis berdasarkan tabel yang telah ditampilkan. Penyajian data secara tabular yaitu memberikan keterangan berbentuk angka. Dimana data disusun dalam baris dan kolom dengan sedemikian rupa sehingga dapat memberikan gambaran hasil keseluruhan dengan menampilkan poin-poin penting yang menunjukkan hasil analisis dari data yang telah diolah menggunakan aplikasi Ms. Excel dan SPSS 18.

Penelitian ini dilakukan setiap ada jadwal pemeriksaan kehamilan pada bulan Juni 2015. Penelitian dilakukan dengan cara mengambil data primer melalui kuesionair yang disebarkan kepada sejumlah pasien terpilih sebagai responden sebanyak 47 orang, dan data sekunder yakni mencatat hasil pemeriksaan Haemoglobin ( $\mathrm{Hb})$ ibu yang menjadi responden. Penelitian ini menggunakan desain penelitian kuantitatif dan pendekatan case control. Variabel yang diteliti adalah kadar Haemoglobin $(\mathrm{Hb})$ ibu hamil pada trimester III sebagai variabel dependen, sedangkan variabel independennya adalah kepatuhan dalam mengkonsumsi tablet Fe selama kehamilan.

\section{Hasil}

Berdasarkan tabel 2 dapat diketahui bahwa usia responden mayoritas adalah pada rentang 20-35 tahun, seluruhnya merupakan ibu hamil trimester III dan melakukan pemeriksaan kehamilan secara rutin, dengan 70,2\% melakukan pemeriksaan sejak awal kehamilan di Puskesmas Kecamatan Pasar Minggu, dengan pendidikan terbanyak yakni $40,4 \%$ SMA dan pekerjaan terbanyak $38,3 \%$ sebagai Ibu Rumah Tangga, serta kadar $\mathrm{Hb}$ pada pemeriksaan kehamilan pertama adalah seluruhnya diatas angka $11 \mathrm{gr} \%$.

Pada variabel independen yakni kepatuhan dalam mengkonsumsi tablet $\mathrm{Fe}$, dari data yang telah diakumulasikan dan disesuaikan dengan kategori skor pada hasil olah angka dengan metode MSI (Method of Succesife Interval) yang telah dijelaskan sebelumnya.

Didapatkan distribusi frekuensi responden menurut kepatuhan dalam mengkonsumsi tablet Fe pada periode bulan Juni tahun 2015, yang telah dijabarkan dalam tabel yang terdiri dari 5 (lima) indikator kepatuhan dalam mengkonsumsi tablet Fe berikut presentasenya sebagai berikut :

Tabel 2. Karakteristik Responden di Puskesmas Kec. Pasar Minggu Tahun 2015

\begin{tabular}{llcc}
\hline Variabel & Kategori & n & \% \\
\hline Umur & $<20$ tahun & 0 & 0 \\
& 20-35 tahun & 37 & 78,7 \\
& $>35$ tahun & 10 & 21,3 \\
Usia & 0 -12 minggu & 0 & 0 \\
Kehamilan & 13-27 minggu & 0 & 0 \\
& $>28$ minggu & 47 & 100 \\
Periksa & Sejak awal kehamilan & 33 & 70,2 \\
Kehamilan & Tidak sejak awal & 14 & 29,8 \\
& kehamilan & & \\
Frekuensi & Rutin & 47 & 100 \\
Periksa & Tidak Rutin & 0 & 0 \\
Kehamilan & & & \\
Pendidikan & SD & 2 & 4,3 \\
& SMP & 12 & 25,5 \\
& SMA & 19 & 40,4 \\
& PT & 14 & 29,8 \\
& Lainnya & 0 & 0 \\
Pekerjaan & IRT & 18 & 38,3 \\
& Karyawan & 17 & 36,2 \\
& Pendidik & 0 & 0 \\
& Wiraswasta & 10 & 21,3 \\
& Lainnya & 2 & 4,2 \\
& $<11$ gr\% & 0 & 0 \\
& \pm 11 gr\% & 39 & 83 \\
& $>11$ gr\% & 8 & 17 \\
\hline
\end{tabular}

Tabel 3. Distribusi Frekuensi Reponden Menurut Kepatuhan dalam Mengkonsumsi Fe di Puskesmas Kec. Pasar Minggu Tahun 2015

\begin{tabular}{lll}
\hline Kepatuhan Konsumsi Tablet Fe & n & \% \\
\hline Sangat patuh & 8 & 17 \\
Patuh & 29 & 61,7 \\
Kurang patuh & 10 & 21,3 \\
Tidak patuh & 0 & 0 \\
Sangat tidak patuh & 0 & 0 \\
\hline
\end{tabular}

Berdasarkan tabel 3 dan pengaturan pengelompokan data berdasarkan akumulasi nilai, dari 47 responden maka dapat dijelaskan, ada 29 responden $(61,7 \%)$ yang patuh mengkonsumsi tablet $\mathrm{Fe}, 10$ responden $(21,3 \%)$ yang kurang patuh, 8 responden (17\%) yang sangat patuh dalam mengkonsumsi Tablet Fe.

Hal ini menunjukkan bahwa dari 5 indikator kepatuhan ibu hamil dalam megkonsumsi tablet $\mathrm{Fe}$ terhadap kadar $\mathrm{Hb}$ 
Tabel 4. Ditribusi Frekuensi Reponden Menurut Kadar $\mathrm{Hb}$

\begin{tabular}{|c|c|c|c|c|c|c|c|c|}
\hline \multirow{2}{*}{$\mathbf{N}$} & \multirow{2}{*}{ Mean } & \multirow{2}{*}{ Median } & \multirow{2}{*}{$\begin{array}{l}\text { Std. } \\
\text { Deviasi }\end{array}$} & \multirow{2}{*}{$\begin{array}{l}\text { Min. - } \\
\text { Max. }\end{array}$} & \multirow{2}{*}{ CI } & \multicolumn{3}{|c|}{$\begin{array}{c}\text { Frekuensi Kadar Hb } \\
(\%)\end{array}$} \\
\hline & & & & & & $\begin{array}{c}\text { Kurang } \\
(<11)\end{array}$ & $\begin{array}{c}\text { Cukup } \\
(\geq 11)\end{array}$ & $\begin{array}{c}\text { Tinggi } \\
(\geq 12)\end{array}$ \\
\hline 47 & 10,95 & 11,5 & 1,05 & $9-12,5$ & $\begin{array}{c}10,64- \\
11,25 \\
\end{array}$ & $\begin{array}{c}15 \\
(31,9 \%)\end{array}$ & $\begin{array}{c}23 \\
(48,9 \%)\end{array}$ & $\begin{array}{c}9 \\
(19,1 \%)\end{array}$ \\
\hline
\end{tabular}

tidak seluruhnya masuk dalam karakteristik responden dalam hal kepatuhan dalam mengkonsumsi tablet Fe.

Dari 5 indikator kepatuhan ibu hamil dalam mengkonsumsi tablet $\mathrm{Fe}$ terdapat 3 indikator yang dimiliki oleh responden, yakni kepatuhan jenis sangat patuh, patuh, dan kurang patuh dalam mengkonsumsi tablet Fe.

Distribusi Frekuensi Responden Menurut Kadar $\mathrm{Hb}$ adalah pada Tabel 4 menunjukkan dari 47 responden, rata-rata kadar $\mathrm{Hb}$ responden $10,95 \mathrm{gr} \%$, median $11,5 \mathrm{gr} \%$, dengan variasi sebaran 1,05, kadar $\mathrm{Hb}$ terendah $9 \mathrm{gr} \%$ dan tertinggi $12,5 \mathrm{gr} \%$. Dari hasil estimasi interval diketahui rata-rata kadar $\mathrm{Hb}$ responden dalam rentang $10,64 \mathrm{gr} \%$ $11,25 \mathrm{gr} \%$, sedang responden yang memiliki kadar $\mathrm{Hb}<9$ (rendah dan sangat rendah) tidak ada. Sedangkan jika dibagi berdasarkan tingkat anemia, maka diketahui terdapat 15 reponden $(31,9 \%)$ yang mengalami anemia sedang dan sisanya tidak anemia $(\mathrm{Hb}>11 \mathrm{gr} \%)$.

Pada analisis korelasi, maka akan sekaligus didapatkan nilai hubungan antara variabel yang diteliti dengan tingkat keeratan yang dicapai dengan melihat dari angka ouput SPSS pada Pearson Correlation (r). Angka tersebut dapat dilihat pada tabel penyajian data analisis korelasi pearson dan $\mathrm{p}$ (value), sebagai berikut :

Tabel 5. Hubungan Kepatuhan Ibu Hamil dalam Mengkonsumsi Tablet Fe terhadap Kadar Hb di Puskesmas Kec. Pasar Minggu Tahun 2015

\begin{tabular}{cc}
\hline Pearson Correlation $(\mathrm{r})$ & $\mathrm{P}($ value $)$ \\
\hline 0,756 & 0,000 \\
\hline
\end{tabular}

Pada tabel 5 diperoleh nilai $\mathrm{p}$ (value) $=$ 0,000 dan nilai $r=0,756$ (positif). Nilai $p<$ 0,05 , menunjukkan terdapat hubungan, dan hubungan tersebut signifikan, antara variabel kepatuhan dalam mengkonsumsi tablet $\mathrm{Fe}$ dengan variabel kadar $\mathrm{Hb}$.

Nilai $r=0,756$ (positif), sehingga dapat disimpulkan hubungan kepatuhan dalam mengkonsumsi tablet $\mathrm{Fe}$ dengan kadar $\mathrm{Hb}$ memiliki hubungan yang sangat kuat/ sempurna/ sangat signifikan dengan arah hubungannya searah/ linier (kepatuhan dalam mengkonsumsi $\mathrm{Fe}$ tinggi maka kadar $\mathrm{Hb}$ tinggi) atau dengan kata lain kepatuhan ibu hamil dalam mengkonsumsi tablet $\mathrm{Fe}$ berpengaruh sangat signifikan terhadap kadar $\mathrm{Hb}$.

Pada analisis bivariat ini, setelah diketahui adanya hubungan anatara dua variabel, dan telah diketahui pula tingkat keeratan antara variabel, maka analisis selanjutnya adalah untuk mengetahui bagaimana variabel independen mempengaruhi variabel dependen, dan seberapa besar porsi pengaruhnya.

Pengaruh variabel independen terhadap variabel dependen dapat dilihat dari output SPSS sebagai berikut:

Tabel 6. Pengaruh Kepatuhan Ibu Hamil dalam Mengkonsumsi Tablet $\mathrm{Fe}$ terhadap Kadar $\mathrm{Hb}$ di Puskesmas Kec. Pasar Minggu Tahun 2015

\begin{tabular}{ccccc}
\hline $\mathbf{R}$ & $\mathbf{P v}$ & \multicolumn{2}{c}{ B } & Pv coef. \\
\cline { 3 - 4 } Sqre. & Anova & Constan & $\begin{array}{c}\text { Kepatuh } \\
\text { Regresi }\end{array}$ & \\
\hline $\begin{array}{c}0,57 \\
2\end{array}$ & 0,000 & $-13,163$ & 0,167 & 0,0000 \\
\hline
\end{tabular}

Berdasarkan tabel 6 diketahui dengan $\mathrm{p}$ (value) dari output anova menunjukkan 0,000 atau $<0,05$ sehingga terdapat perbedaan ratarata pada populasi dan kenaikan kepatuhan dalam mengkonsumsi Fe berpengaruh terhadap kenaikan kadar $\mathrm{Hb}$. P (value) pada output regresi memiliki nilai yang sama pada output anova yakni $<0,05$, berarti kepatuhan dalam mengkonsumsi tablet $\mathrm{Fe}$ pengaruhnya signifikan terhadap kadar $\mathrm{Hb}$. Nilai R-Square 
0,572 yang menunjukkan kepatuham minum tablet Fe berpengaruh 57,2\% terhadap kadar $\mathrm{Hb}$ dan sisanya dipengaruhi oleh faktor lain.

\section{Pembahasan}

\section{Kepatuhan Konsumsi Tablet Fe}

Perilaku kepatuhan ibu hamil dalam mengkonsumsi tablet $\mathrm{Fe}$ berdasarkan hasil penelitian di Puskesmas Kecamatan Pasar Minggu pada periode bulan Juni 2015 menunjukkan dari 47 responden terdapat 29 responden $(61,7 \%)$ yang patuh mengkonsumsi tablet $\mathrm{Fe}, 10$ responden $(21,3 \%)$ yang kurang patuh, 8 responden $(17 \%)$ yang sangat patuh dalam mengkonsumsi Tablet Fe. Sedangkan responden yang memiliki tidak patuh dan sangat tidak patuh dalam mengkonsumsi tablet Fe tidak ada.

Menurut data hasil Riskesdas Kementerian Kesehatan RI yang menyebutkan bahwa hanya $33,1 \%$ saja ibu hamil yang rutin mengkonsumsi tablet $\mathrm{Fe}^{22} \mathrm{Hal}$ ini menunjukkan data tersebut tidak sesuai dengan data yang hasil penelitian yang menyebutkan bahwa rata-rata ibu hamil patuh dalam mengkonsumsi tablet $\mathrm{Fe}$ sebesar $61,7 \%$ dan bahkan ada $12 \%$ yang sangat patuh dengan mengkonsumsi 2 tablet Fe perhari.

Hasil tersebut juga menunjukkan ketidaksesuaian dengan teori dari Prawirohardjo (2010) yang menyebutkan bahwa hanya 15 tablet yang rata-rata dikonsumsi oleh ibu hamil. Berdasarkan hasil penelitian pada penilaian ketepatan dosis dan ketepatan frekuensi menunjukkan jumlah tablet $\mathrm{Fe}$ yang dikonsumsi responden yang patuh adalah 1 tablet perhari dan pada ibu yang sangat patuh adalah 2 tablet perhari. Jumlah tersebut didasarkan pada advise dari petugas kesehatan di Puskesmas Kec. Pasar Minggu, yang hal ini berdampak baik terhadap kadar $\mathrm{Hb}$ ibu hamil.

Menurut Handayani (2013) kepatuhan ibu hamil dalam mengkonsumsi tablet $\mathrm{Fe}$ sangat dipengaruhi oleh pengetahuan dengan rata-rata jumlah konsumsi tablet Fe oleh adalah 107 tablet, yakni sekitar 1 tablet perhari, dengan tingkat kepatuhan $64,7 \%$ dan $88 \%$ ibu hamil patuh dalam mengkonsumsi tablet $\mathrm{Fe}^{24}$

Asumsi peneliti berdasarkan data yang telah ada bahwa kepatuhan ibu hamil dalam mengkonsumsi tablet $\mathrm{Fe}$ sudah baik, yakni
$61,7 \%$ telah patuh dalam mengkonsumsi tablet $\mathrm{Fe}$ dengan konsumsi pada kisaran 1 (satu) tablet perhari.

Namun pada pola konsumsi harus diperbaiki yakni menekankan pada konsumsi tablet Fe minimal 90 tablet selama kehamilan. Sehingga apabila setelah usia kehamilan lanjut (trimester III) ibu hamil belum merasa mengkonsumsi minimal 90 tablet Fe maka ibu hamil tersebut akan bisa memperbaiki dengan melakukan cek kadar $\mathrm{Hb}$ dan konsultasi kepada petugas kesehatan secara mandiri. Untuk itu promosi kesehatan tentang pentingnya konsumsi tablet $\mathrm{Fe}$ sangat diperlukan dan menekankan pada konsumsi tablet $\mathrm{Fe}$ yang baik dan benar yakni patuh dengan dosis, cara, dan frekuensi sesuai dengan anjuran petugas kesehatan.

\section{Kadar Hb}

Rekapitulasi kadar $\mathrm{Hb}$ ibu hamil berdasarkan hasil penelitian di Puskesmas Kecamatan Pasar Minggu pada periode bulan Juni 2015 menunjukkan bahwa dari 47 responden, rata-rata kadar $\mathrm{Hb}$ responden adalah 10,95gr\%, kadar $\mathrm{Hb}$ terendah $9 \mathrm{gr} \%$ dan tertinggi $12,5 \mathrm{gr} \%$. Dari hasil penelitian menunjukkan bahwa 95\% responden memiliki kadar $\mathrm{Hb}$ dalam rentang 10,64gr\% - 11,25gr\%, sedang responden yang memiliki kadar $\mathrm{Hb}<9$ tidak ada. Sedangkan jika dibagi berdasarkan tingkat anemia, maka diketahui terdapat 15 reponden $(31,9 \%)$ yang mengalami anemia sedang dan sisanya tidak anemia $(\mathrm{Hb}>11 \mathrm{gr} \%)$.

Hasil penelitian ini menunjukkan 31,9\% responden yang memiliki kadar $\mathrm{Hb}$ dibawah $11 \mathrm{gr} \%$. Hasil tersebut menunjukkan terdapat kesesuaian dengan data dari Riskesdas Kementerian Kesehatan RI (2013) yang menyebutkan terdapat prevalensi anemia sebesar $37,1 \%$ pada ibu hamil dan kejadian anemia di Puskesmas Kec. Pasar Minggu sebesar $30,6 \%$ pada ibu hamil. ${ }^{25}$

Seluruh responden mengaku telah mendapatkan tablet $\mathrm{Fe}$, hal ini menunjukkan kesesuaian data dari Laporan Tahunan Puskesmas Kecamatan Pasar Minggu (2014) tentang distribusi tablet $\mathrm{Fe}$ yang mencapai $94,8 \%{ }^{26}$

Dinilai dari ketepatan dosis dan frekuensi, rata-rata ibu hamil yang memiliki $\mathrm{Hb}$ tinggi karena mengkonsumsi 2 tablet Fe perhari, dan 
pada ibu hamil yang memiliki $\mathrm{Hb}<11 \mathrm{gr} \%$ memiliki riwayat kepatuhan dosis dan frekuensi yang kurang baik ( $\leq 1$ tablet per hari).

Pada penelitian yang dilakukan oleh Litasari et.al. (2012) menunjukkan rata-rata kadar $\mathrm{Hb}$ ibu hamil adalah 9,83\%. Hal ini juga sesuai dengan penelitian yang dilakukan oleh Sifik dkk yang menyebutkan bahwa pada hasil penelitian yang dilakukannya didapatkan ratarata kadar $\mathrm{Hb}$ ibu hamil adalah 11,42gr\%. Pada penelitian eksperimental yang dilakukan oleh Samanta (2009) yang menyebutkan bahwa kadar $\mathrm{Hb}$ rata-rata ibu hamil sebelum mengkonsumsi tablet Fe adalah 11,56gr\% dan setelah mengkonsumsi tablet $\mathrm{Fe}$ meningkat menjadi $12,11 \mathrm{gr} \%$, dengan rata-rata kenaikan $0,55 \mathrm{gr} \%{ }^{27}$

Asumsi peneliti dengan rata-rata kadar $\mathrm{Hb}$ ibu yang sudah mendekati angka normal yakni 11 gr\%, sehingga mayoritas responden tidak anemia. Namun, masih terdapat $31,9 \%$ yang masih memiliki $\mathrm{Hb}$ dibawah $11 \mathrm{gr} \%$. Hal ini perlu mendapatkan perhatian lebih karena dengan ditribusi tablet $\mathrm{Fe}$ yang mendekati angka $100 \%$ pada FeIII, maka tingkat kejadian anemia seharusnya tidak sampai pada angka $10 \%$.

Terdapat berbagai penyebab perbedaan hasil pada pemeriksaan $\mathrm{Hb}$, seperti perbedaan hasil $\mathrm{Hb}$ pada mesin dan manual, maka hendaknya pemerintah juga melakukan sosialisasi kriteria pemeriksaan $\mathrm{Hb}$ yang baik dan benar, sehingga dapat mengurangi kekhawatiran kemungkinan kesalahan dalam pemeriksaan $\mathrm{Hb}$.

\section{Konsumsi Tablet Fe terhadap Kadar Hb}

Pada analisis bivariate ini sebelum dilakukan uji korelasi dan regresi maka data harus memenuhi syarat, yakni lulus pada uji normalitas dan uji linearitas data. Pada uji normalitas menggunakan uji Shapiro-Wilk mendapatkan hasil p (value) 0,091, dan uji linearitas mendapatkan hasil p (value) 0,635. Keduanya memiliki nilai p (value) > 0,05, sehingga data dinggap normal dan linear, sehingga data diijinkan untuk dilakukan uji korelasi pearson.

Pada uji korelasi menggunakan uji korelasi pearson, didapatkan hasil $\mathrm{p}$ (value) 0,000 yang berarti kepatuhan ibu hamil dalam mengkonsumsi tablet Fe memiliki hubungan yang signifikan terhadap kadar Hb. Dan dengan Koefisien korelasi (r) bernilai 0,756 menunjukkan hubungan tersebut positif/ linier dan hubungannya sangat erat/ sangat signifikan/ sempurna. Sehingga dari hasil uji korelasi pearson dapat disimpulkan laju kenaikan perilaku kepatuhan sangat signifikan pengaruhnya terhadap laju kenaikan kadar $\mathrm{Hb}$ dengan arah laju hubungan positif.

Hal ini menunjukkan terdapat kesesuaian antara hasil penelitian dan pendapat para ahli yang menghimbau agar ibu hamil diberikan suplementasi besi sebanyak 60mg dan memberikan dosis lebih pada ibu yang anemia atau beresiko anemia, baik secara oral maupun parenteral dapat membantu menaikkan kadar $\mathrm{Hb} \quad 2 \mathrm{gr} \%$ sekitar 3-4 minggu. Dengan mengkonsumsi Fe yang sesuai dengan anjuran maka kebutuhan zat besi ibu dan bayi diharapkan akan terpenuhi.

Dari hasil penelitian menunjukkan kadar $\mathrm{Hb}$ ibu hamil trimester III yang melakukan pemeriksaan di Puskesmas Pasar Minggu cukup bagus, meskipun adasekitar 31,9\% yang mengalami anemia ringan. Pada ibu hamil yang memiliki kadar $\mathrm{Hb}$ yang baik dengan proporsi $88,1 \%$ konsumsi Fe mereka 2 tablet perhari, hal ini berbeda dengan instruksi dari pemerintah yang menghimbau agar konsumsi Fe 1 tablet perhari. Namun, bukan perarti berbeda tidak baik, justru ibu hamil yang mengkonsumsi Fe lebih dari 1 tablet perhari memiliki kadar $\mathrm{Hb}$ diatas $11 \mathrm{gr} \%$.

Jika perilaku kepatan ibu hamil dalam mengkonsumsi tablet $\mathrm{Fe}$ berhubungan signifikan terhadap kadar $\mathrm{Hb}$ maka hal tersebut ternyata hanya menyumbang sebesar $57,2 \%$, sisanya dipengaruhi oleh faktor lain. Hal tersebut dibuktikan dengan data hasil akumulasi yang di uji menggunakan regresi sederhana memberikan hasil R-Square 0,572, yang berarti kepatuhan ibu hamil dalam mengkonsumsi tablet $\mathrm{Fe}$ memiliki proporsi $57,2 \%$ dan sisanya adalah faktor lain.

Jika dinilai berdasarkan frekuensi, dosis, dan cara konsumsi tablet Fe ibu hamil, maka diketahui bahwa rata-rata ibu hamil memiliki frekuensi konsumsi, dosis, dan cara minum tablet $\mathrm{Fe}$ yang benar. Misalnya ibu mengkonsumsi tablet Fe setiap hari sejak awal kehamilan, 1 tablet, dengan air putih, bukan dengan teh, kopi, atau susu. Dan hampir seluruhnya mengaku tidak mengalami mual sehingga tablet Fe biasa diminum bukan pada 
saat menjelang tidur. Namun dengan perilaku yang sudah benar ini masih terdapat $39,1 \%$ yang mengalami anemia. Hal ini dikarenakan perilaku dalam mengkonsumsi tablet $\mathrm{Fe}$ hanya memiliki proprosi 57,2\%, sehingga masih terdapat $42,8 \%$ factor lain yang mempengaruhi kadar $\mathrm{Hb}$ selain kepatuhan dalam mengkonsumsi tablet Fe.

Hal ini sesuai dengan teori para ahli yang telah dijelaskan pada bab tinjauan pustaka yang menyebutkan bahwa anemia memiliki berbagai klasifikasi antara lain karena defisiensi besi, defisiensi asam folat, akibat penyakit kronis, perdarahan akut, dan kelainan darah. Selain itu jika ibu memiliki tingkat beban kerja yang berat dan tingkat stress yang tinggi dapat mengalami anemia, atau usia kehamilan yang melebihi 35 tahun, sehingga meskipun patuh dalam mengkonsumsi tablet Fe namun tidak diikuti oleh kecukupan nutrisi lain akibat penggunaan energi yang berlebih dan kurangnya nafsu makan akibat stress.

Adanya ketimpangan ditribusi tablet $\mathrm{Fe}$ yang tinggi dengan masih tinggi nya kejadian anemia, hal ini sejalan dengan penelitian yang dilakukan oleh Anasari yang menyebutkan bahwa terdapat $50,9 \%$ ibu hamil yang patuh dalam mengkonsumsi tablet $\mathrm{Fe}$ dan 50\% masih mengalami anemia pada kehamilan. ${ }^{28}$

Ditinjau dari uji korelasi dan regresi terdapat kesesuaian hasil penelitian ini dengan penelitian yang dilakukan oleh Umami et.al. (2012) yang menyebutkan bahwa dari $100 \%$ responden yang telah diberikan tablet $\mathrm{Fe}$ sejumlah 90 tablet terdapat $85,7 \mathrm{gr} \%$ patuh mengkonsumsi tablet $\mathrm{Fe}$, dan peningkatan kadar $\mathrm{Hb}$ setelah mengkonsumsi $\mathrm{Fe}$ adalah $0,7 \mathrm{gr} \%$ dari $10,9 \mathrm{gr} \%$ menjadi $11,6 \mathrm{gr} \%$ sehingga hubungan laju peningkatan kepatuhan dengan laju kenaikan kadar $\mathrm{Hb}$ adalah positif.

Hal ini pun sejalan dengan penelitian yang dilakukan oleh Wipayani yang menyebutkan bahwa terdapat hubungan tang signifikan dan positif antara sikap kepatuhan ibu hamil dalam mengkonsumsi tablet $\mathrm{Fe}$ dengan kadar $\mathrm{Hb}^{29}$

Selain itu perlu ditekankan, meskipun ibu hamil telah diberikan suplemen, ibu hamil tetap harus memenuhi kebutuhan nutrisi dari bahan alami karena sifat suplemen adalah nutrisi tambahan bukan utama. Seperti, kebutuhan karbohidrat dan protein yang tidak hanya dari susu ibu hamil tapi juga dari nasi dan lauk pauk, kebutuhan vitamin dan mineral yang tidak hanya dipenuhi oleh suplemen namun juga dari buah dan sayuran, sehingga suplemen tablet $\mathrm{Fe}$ yang dikonsumsi bisa bermanfaat optimal.

\section{Kesimpulan}

Berdasarkan hasil distribusi frekuensi kepatuhan ibu hamil dalam mengkonsumsi tablet Fe terdapat $61,7 \%$ ibu hamil yang patuh, $21,3 \%$ kurang patuh dan $17 \%$ yang sangat patuh dalam mengkonsumsi tablet Fe.

Berdasarkan hasil distribusi frekuensi kadar $\mathrm{Hb}$ didapatkan rata-rata kadar $\mathrm{Hb}$ 10,95\%, kadar $\mathrm{Hb}$ terendah 9gr\% dan tertinggi $12,5 \mathrm{gr} \%$, dan $31,9 \%$ ibu hamil yang mengalami anemia sedang ( $\mathrm{Hb} 9 \mathrm{gr} \%-10 \mathrm{gr} \%)$.

Berdasarkan hasil uji korelasi dan regresi, kepatuhan dalam mengkonsumsi tablet $\mathrm{Fe}$ berpengaruh sangat signifikan/ sangat kuat terhadap kadar $\mathrm{Hb}$ dan laju hubungannya positif/ searah, yakni jika kepatuhan ibu hamil dalam mengkonsumsi tablet $\mathrm{Fe}$ meningkat maka kadar $\mathrm{Hb}$ ibu hamil akan naik, dengan proporsi pengaruhnya sebesar $57,2 \%$.

\section{Saran}

Peneliti selanjutnya diharapkan untuk bisa melakukan penelitian yang lebih mendalam untuk mengetahui lebih lanjut pengaruh kepatuhan ibu hamil dalam mengkonsumsi tablet Fe terhadap kadar $\mathrm{Hb}$ ibu hamil, dengan melakukan penelitian perbandingan kadar $\mathrm{Hb}$ ibu hamil pada wilayah dengan cakupan tablet Fe terendah dan tertinggi seperti di antara wilayah provinsi DIY Yogyakarta yang memiliki cakupan konsumsi tablet Fe tertinggi dan Provinsi Lampung yang memiliki cakupan konsumsi tablet $\mathrm{Fe}$ terendah di Indonesia. Selain itu, dengan diketahuinya proporsi faktor kepatuhan dalam mengkonsumsi tablet $\mathrm{Fe}$ hanya $57,2 \%$, maka diharapakan peneliti selanjutnya dapat menambahkan variabel lain dalam penelitian yang memiliki pengaruh dalam menentukan kadar $\mathrm{Hb}$, seperti asupan asam folat, pemenuhan kebutuhan sayur dan buah dalam pola makan, penyakit bawaan, factor stress dan pekerjaan.

\section{Daftar Pustaka}

1. Soetijiningsih. Tumbuh Kembang Anak. EGC: Jakarta; 2012. 
2. Evelin PN dan Djamaludin N. Panduan Pintar Merawat Bayi dan Balita. Jakarta: Wahyu Media; 2010.

3. Aisyah S. Kontribusi Pola Asuh Orangtuan Terhadap Tingkat Agresivitas anak. [Jurnal] MEDTEK, Vol. $2 ; 2010$

4. Dewi T. Pola Asuh Ibu, Kejadian Diare, dan Pertumbuhan Sampai 4 Bulan pada Bayi yang Mengalami Hambatan Pertumbuhan dalam Rahim. Jurnal Media Medika Indonesia 43 (3): 122-8; 2008.

5. Susanti. Peran Wanita Dalam Pengasuhan Dan Perawatan Kesehatan Anak Balita. Pusat Penelitian Studi Wanita Lembaga Penelitian Universitas Airlangga; 2008.

6. Notoatmodjo S. Metodologi Penelitian Kesehata. Jakarta: Rineka Cipta;2010.

7. Hastono SP. Analisis Data Kesehatan. Depok: Fakultas Kesehatan Masyarakat Universitas Indonesia; 2006.

8. Werdiningsih ATA dan Astarani K. Peran Ibu Dalam Pemenuhan Kebutuhan Dasar Anak Terhadap Perkembangan Anak Usia Prasekolah Role In Meeting The Needs Of Mother On Child Development Preschoolers. Jurnal : STIKES RS Baptis Kediri;2012.Fatimah E. Psikologi Perkembangan (Perkembangan Peserta Didik). Pustaka Setia : Bandung; 2006.

9. Hayati F dan Mamat N. Pengasuhan dan Peran Orang Tua (Parenting) serta Pengaruhnya Terhadap Perkembangan Sosial Emosional
Anak di PAUD Banda Aceh, Indonesia. Jurnal Buah Hati Vol 1, No 2 (2014): 17-30.

10. Ireson J. Exploring connections between individual and culture at home and school. In Ireson, J. (ed). Learners, Learning, and Educational Activity. New York: Routledge; 2008 .

11. Husnah. Hubungan Pola Makan, Pertumbuhan dan Stimulasi dengan Perkembangan Anak Usia Balita Di Posyandu Melati Kuta Alam Banda Aceh.Jurnal Kedokteran Syiah Kuala. Vol. 15 No 2 (2015): 66-71.

12. Rahmaulina ND dan Hastuti D. Hubungan pengetahuan ibu tentang gizi dan tumbuh kembang anak serta stimulasi psikososial dengan perkembangan kognitif anak usia 2-5 tahun. Jurnal Ilmu Keluarga dan Konsumen. Vol. 1 No 2 (2008) : 1-11.

13. Wulan NR. [Online].; 2012 [cited 2017 Oktober10.From:http://repository.uji.ac.id/100/ sk/I/0/00/00/001015/gizi.NISSA\%250RAHM A\%250 WULAN-8515525419-abstract.pdf.

14. Gunawan G, Fadlyana E, Rusmil K. Hubungan Status Gizi dan Perkembangan Anak Usia 1-2 Tahun. Sari Pediatri. Agustus 2011; 13(2).

15. Yulia C, dkk. Pola Asuh Makan dan Kesehatan Anak Balita pada keluarga wanita pemetik teh di PTPN VIII Pangalengan.2008. diunduh di id.pdfsb.com/jurnal+kesehatan+pada+balita. Diakses pada 10 Oktober 2017. 